\title{
THE SAYYIDS OF PERAK: A PRELIMINARY STUDY ON THEIR ORIGINS AND INFLUENCES IN THE PERAK SOCIETY
}

\author{
Mohamad Hazizie bin Sulkafle* \\ International Institute of Islamic Thought and Civilisation, \\ International Islamic University Malaysia (IIUM), Malaysia
}

\begin{abstract}
This article would like to highlight one sayyids family which for a long time had been marginal in the academic world - the Sayyids of Jamalullail of Perak. This article argues that they have contributed significantly to the Islamisation and the administration of the Perak Sultanate since its establishment in the early $16^{\text {th }}$ century until the early $20^{\text {th }}$ century, particularly through their position as Orang Kaya Menteri Paduka Tuan for several generations. Hence, utilizing several manuscripts available in the National Archive of Malaysia and the SOAS Digital Collections, and supported by other relevant sources, their origins and contributions to the Perak Sultanate will be discussed and highlighted accordingly. Even at one time, these sayyids dominated Orang Besar Empat offices of the Perak Sultanate, except Temenggung. As Orang Kaya Menteri Paduka Tuan who is in charge of religious matters, these Sayyids compiled a set of laws known as the Ninety-nine Laws of Perak which signify an intellectual legacy of the Malay society. This set of laws is important in understanding the Islamisation process and the interactions between Islam and adat in Malay society.
\end{abstract}

Keywords: Jamalullail of Perak, the Hadhramis, Orang Kaya Menteri Paduka Tuan, the Ninety-nine Laws of Perak, Islamisation of Perak.

\section{Introduction}

The Malays had for centuries tended to look upon all Arabs, whatever their origins, as the direct inheritors of the wisdom of Islam, and on Sayyids in particular (kinsmen of the Prophet) as possessed of unexampled piety and religious merit. ${ }^{1}$

Above statement by William R. Roff shown how the Arabs, especially the sayyids, influenced the Malay society significantly, particularly in terms of religious knowledge. The interaction between the Arabs and Malays were begun since ancient time. ${ }^{2}$ The interactions happened when the Arabs stopped at certain ports surrounding Malay-Indonesian Archipelago in their voyages from Arabian Peninsula to the East and vice versa. At the same time, the Malay sailors also reached Arabian Peninsula particularly ports in Yaman for trades. ${ }^{3}$ Ports in Yaman were known for centuries as collection points for Eastern products before being brought through lands route to Makkah, then to Biläd al-Shams (areas surrounding modern-day Syria, Jordan, and Palestine) and being sold to the Western traders for the European market. ${ }^{4}$

Despite that, evidence on direct interactions between these two societies become clearer during the seventh century CE. These direct interactions, for example, proven by the 
existence of an Arab settlement in the west coast of Sumatera as early as 671,5 and still existed afterwards, at least until $674 .{ }^{6}$ Other than that, beginning from the ninth century CE onwards, the Malay-Indonesian Archipelago was mentioned in the Arabs sources. ${ }^{7}$ Among those sources were 'Ajaib al-Hind by Buzurg of Ramhurmuz, Akhbār aș-Șin wa'l-Hind, travel records of Abu Zaid and Abu Dulaf, Kitāb al-Masālik wa'l-Mamālik by Ibn Khurdādhbih, Kitāb Nuzhat al-Mushtāq fi Ikhtirāq al-ĀAāq by al-Idrisī, Mu'jam al-Buldān by Yaqūt, and travel records by Ibn Bațutạh. ${ }^{8}$ Hence, it can be concluded that during these periods, there was already constant interaction between the two parts of the world.

The sayyids of Hadhramawt were among the significant groups of the Arabs who arrived in the Malay-Indonesian Archipelago. Although general discussions tend to claim that the huge wave of the arrival of the sayyids of Hadramawt to the Malay-Indonesian Archipelago only occurred during the $17^{\text {th }}$ century onwards, ${ }^{9}$ however there are also possibilities that they had arrived at the Malay-Indonesian Archipelago as early as the $14^{\text {th }}$ and $15^{\text {th }}$ century in small numbers since as early as the $14^{\text {th }}$ century, they had travelled out to Africa and India. ${ }^{10}$ From India, they ventured to the Malay-Indonesian Archipelago. Ulrike Freitag supported this early migration when mentioning that as early as the $13^{\text {th }}$ century, the sayyids had already reached India. Their numbers increased in the $16^{\text {th }}$ century and reached its peak in the $17^{\text {th }}$ century. ${ }^{11}$ Syed Muhammad Naquib al-Attas also argued that Tuan Masha'ika, one of the prominent figures in the Islamisation of Sulu was a sayyid of Hadhramawt and descended from Alawi bin Muhammad al-Faqīh al-Muqaddam bin 'Ali bin Muhammad Ṣāhịib Marbāt and he had already arrived in Sulu between 1270 or $1275 .{ }^{12}$

This early arrival seemed not impossible. A research done by R. Michael Feener and Michael F. Laffan found out that there was a Hadhrami figure name Abū 'Abd Allāh Mas'ūd bin Muhammad al-Jāwi who at least lived during the $14^{\text {th }}$ century. This was because his name was included in the $15^{\text {th }}$ century collection of Sufi biographies, the Tabaqāt al-Khawāss by Shihāb al-Dīn Aḥmad al-Sharjī (1410 - ca. 1487/8). ${ }^{13}$ This "al-Jāwī" nisba made him as someone with a strong connection with the Malay-Indonesian Archipelago since people in this archipelago usually referred to as Jawi people by the Arabs. ${ }^{14}$ They further postulated that it is possible "that either he (or indeed his father) had spent some part of their lives in Southeast Asia. Perhaps he had even been born there to a local mother". ${ }^{15}$

The sayyids referred to in this discussion are the descendants of the Prophet Muhammad S.A.W. from his grandson Sayyidina Hussein R.A. These sayyids began to settle in Hadramawt after the arrival of Ahmad bin Isa al-Muhajir who migrated from Basrah, Iraq due to oppression from the Abbasids rulers. This migration happened in 929 CE. Since then, the descendants of Ahmad bin Isa al-Muhajir grew and dominated the socio-political situation in Hadramawt. ${ }^{16}$ Those sayyids who came to Malay-Indonesian Archipelago claimed themselves from this lineage. ${ }^{17}$ As the descendants of the Prophet Muhammad S.A.W. or Ahl al-Bayt, they were usually respected and revered by the Malays.

Mahayudin Haji Yahaya had come out with his book, Sejarah Orang Syed di Pahang. ${ }^{18}$ Numerous researches also already been done on the sayyids of Johor, Singapore, and Indonesia. The family of al-Attas and al-Saqqaf for example, are among the famous sayyids families in the Malay-Indonesian Archipelago. Even one of the sultanates in Malaysia was founded by a sayyid family, the Jamalullail of the Perlis Sultanate. However, another branch of the Jamalullail family, the Jamalullail of Perak is being marginal in the academic world and being less discussed. Mohammad Redzuan Othman and Abdul Rahman 
Tang only briefly discussed them in their respective articles. ${ }^{19}$ Hence, this study would like to achieve the following objectives:

1) To find out when the sayyids of Jamalullail arrived in Perak

2) To understand to connections between the sayyids of Jamalullail with the Perak royal family

3) To explain the contribution of the sayyids of Jamalullail in the administration of the Perak Sultanate in particular and the Islamisation of Perak society in general

\section{The First Sayyid in Perak: Sayyid Hussein al-Faradz Jamalullail}

The sayyids from the Jamalullail family that first arrived in Perak was Sayyid Hussein alFaradz Jamalullail. He was reputed to be the first religious teacher to the first Sultan of Perak. ${ }^{20}$ According to history, the first Sultan of Perak was Sultan Muzaffar Shah I who reigned in the $16^{\text {th }}$ century $(1528-1549) .{ }^{21}$ Hence, this made Sayyid Hussein al-Faradz Jamalullail's arrival was in the $16^{\text {th }}$ century. However, according to R.O. Winstedt, Sayyid Hussein al-Faradz Jamalullail only arrived in Perak in the $17^{\text {th }}$ century. ${ }^{22}$ There are contradictions of facts here. Hence, to solve this issue, the sources utilized by Winstedt need to be scrutinized further. For the status of Sayyid Hussein al-Faradz Jamalullail as the first religious teacher of the first Sultan of Perak, Winstedt referred to Maxwell. However, Maxwell did not mention who was that "the first Sultan of Perak". Most probably Winstedt turns to Hikayat Misa Melayu to answer that question. This was because not long after he published his article on "The Hadramaut Saiyids of Perak and Siak" in 1919; he also published his edition of Hikayat Misa Melayu in the same year. ${ }^{23}$ In his summary of Hikayat Misa Melayu, he stated "The first ruler of Perak was Marhum Jalilullah,..." without any further comments. ${ }^{24}$

According to Hikayat Misa Melayu, the first Sultan of Perak was Marhum Jalilullah. ${ }^{25}$ Marhum Jalilullah mentioned here was referred to Sultan Muzaffar Shah II who reigned in the $17^{\text {th }}$ century $(1636-1653){ }^{26}$ So far, the claim made by Winstedt seems did not problematic. However, according to the official genealogy of the Perak's sultans, Sultan Muzaffar Shah II was the tenth sultan, not the first sultan. ${ }^{27}$ The answer lies within a proper understanding on the historiography of Hikayat Misa Melayu. Hikayat Misa Melayu was written by Raja Chulan ibn Raja Hamid, a close relative of Sultan Iskandar Zulkarnain, the $15^{\text {th }}$ ruler of Perak (1756-1770). ${ }^{28}$ Being reputed as who "at that time was the cleverest man in Perak at prose and verse", ${ }^{29}$ Raja Chulan primarily recorded events that occurred between 1742 until 1778 in his Hikayat Misa Melayu. ${ }^{30}$

Hikayat Misa Melayu was primarily significant as a historical narrative to uplift the legitimacy of Sultan Muzaffar Shah II's lineage as ruler of Perak. ${ }^{31}$ With the death of the ninth Sultan of Perak; Sultan Salehuddin (1630-1635) died also the Melaka line from the male side in the Perak royal family. ${ }^{32}$ Sultan Salehuddin died without leaving any princes. Perak's throne was vacant for almost a year. Only in 1636, Sultan Muzaffar Shah II being installed as Sultan of Perak. ${ }^{33}$ Then, who was this Sultan Muzaffar Shah II? Sultan Muzaffar Shah II was not closely and directly related to any previous sultans of Perak. Known as Raja Sulong before being installed as sultan, he was a prince from the court of Siak who married with the descendants of Sultan Muzaffar Shah I. ${ }^{34}$ Only with that capacity, together with the 
support of Sultan of Acheh at that time (Sultan Iskandar Thani, 1636 - 1641); he was able to ascend the throne of Perak. ${ }^{35}$

Hence, the title of Sultan Muzaffar Shah II as "the first Sultan of Perak" in Misa Melayu must be understood in this context. ${ }^{36}$ The title was not to claim that he was the first Sultan who founded the Perak Sultanate, but he was the first Sultan of Perak who founded a new dynasty in the Sultanate of Perak. Started with him, subsequent sultans of Perak only connected with the first Sultan of Perak (Sultan Muzaffar Shah I, 1528-1549) through the female line. This was further supported by opinions put forward by Barbara Watson Andaya and Jelani Harun, respectively:

Having established this proud heritage, Raja Chulan moves on immediately to the mid-seventeenth century, to al-Marhum Jalilu'llah, whom he calls the 'first' ruler of Perak. In a sense, he was correct, for other genealogies show that this prince, Sultan Muzaffar of Siak, himself descended from the Bukit Si Guntang line, had begun a new dynasty in Perak by marrying the princess who was the last survivor of the old lineage. ${ }^{37}$

According to history ... . with the demise of Sultan Sallehuddin Shah (16301635), the ninth sultan of Perak ended the Perak Sultanate lineage from the male side. The tenth sultan of Perak, Sultan Mudzafar Shah II was descendants of the king of Siak who married one of the descendants of Sultan Mansur Shah I . . . from this marriage, born the next sultans of Perak with descended from Malacca Sultanate lineage from the female side. Maybe due to this reason, Raja Chulan began Misa Melayu with the era of Sultan Mudzafar Shah II, his grandfather who came from Siak. ${ }^{38}$

However, in his later work, A History of Perak which was first published in 1934, Winstedt seemed to be alert with this fact. Hence, it can be concluded that his confusion only occurred in his earlier researches on Perak Sultanate; on the origins of sayyids in Perak and Hikayat Misa Melayu. Perhaps, it is more accurate to say that the confusion occurred due to Winstedt's mistake in reading and understanding a phrase in Hikayat Misa Melayu which stated:

Sebermula, adapun kepada zaman raja-raja ini di dalam Negeri Perak Dar alRidhuan ini pertama-tama Almarhum Jalilullah yang kesepuluh daripada Almarhum Tanah Abang iaitu Sultan Muzaffar Shah raja yang pertama di dalam negeri ini ... ${ }^{39}$

In the nutshell, from the above discussions, it can be concluded that the arrival of Sayyid Hussein al-Faridz Jamalullail to Perak occurred in the $16^{\text {th }}$ century, not in the $17^{\text {th }}$ century. The confusion arose due to the misunderstanding of the information existed in the sources available. 


\section{Sayyids Hussein al-Faradz and His Descendants}

Sayyid Hussein al-Faradz Jamalullail and his descendants played significant and influential roles in the Sultanate of Perak throughout history. R.J. Wilkinson stated that they "played a great part in the little Perak world" ${ }^{40}$ Meanwhile, Mohammad Redzuan Othman stated that "all the four great offices of the state, except Temenggong, were once held by them". ${ }^{4}$ Hence, the following discussion will look upon those influential roles played by them.

The sayyids of Perak were well-known for their monopoly of the office of Orang Kaya Menteri Paduka Tuan since the early $18^{\text {th }}$ century up to the middle of the $19^{\text {th }}$ century. Sayyid Hussein al-Faradz Jamalullail, the patriarch of the family of Jamalullail of Perak was being reputed as the first religious teacher to the first Sultan of Perak and the first one to be appointed as Orang Kaya Menteri Paduka Tuan. ${ }^{42}$ This position was one of the Orang Besar Empat Perak ${ }^{43}$ which according to Susunan yang Pertama Adat Lembaga Orang-orang Melayu di dalam Negeri Perak Darul Ridzuan daripada Zaman Purbakala:

(Yang keempat) Orang Kaya Menteri Paduka Tuan hakim besar di atas perkara syarak dan adat (masa Kerajaan yang Kedua) ialah yang menjalankan Undangundang Sembilan Puluh Sembilan istiadat kerajaan Negeri Perak kapitnya Orang Kaya-kaya Imam Paduka Tuan bagi menolong di atas perkara syarak. ${ }^{44}$

The first from his descendants who succeeded him was Sayyid Hussein bin Sayyid Jalaluddin, appointed by Sultan Muzaffar Shah III (1728-1756). Yet, there existed a huge gap of 200 years between him and Sayyid Hussein al-Faradz Jamalullail. M.A. Fawzi Basri only mentioned one person who holds this title after Sayyid Hussein al-Faradz Jamalullail, which was Tuk Manjoi Shahor Keramat Tinggal di Ipoh. ${ }^{45}$ Meanwhile, in Hikayat Misa Melayu, there was a figure name Faqih Yusuf who holds this title before Sayyid Hussein bin Sayyid Jalaluddin, also under the same Sultan Muzaffar Shah III. ${ }^{46}$

This huge gap perhaps can be explained by two reasons. The first reason was maybe due to a lack of written documents that survived the period. The mentioning of Sayyid Hussein bin Sayyid Jalaluddin as Orang Kaya Menteri Paduka Tuan was only available in Hikayat Misa Melayu, the earliest written sources available for the history of the Perak Sultanate. Even this Hikayat Misa Melayu only covered a certain period of the history of the Perak Sultanate, as mentioned earlier.

The second reason was maybe due to the unstable situation in Perak for those 200 years of gap. This period witnessed the subjugation of Perak by the Acheh Sultanate in her struggles for influence in the Straits of Malacca with the Johor Sultanates. Hence, possibly any matters related to shara $\bar{a}^{\prime}$ was referred directly to the Acheh Sultanate, and there was no need for any person to hold this title throughout that period. After all, further research needs to be done to answer this issue. Perhaps, the oral history circulated among the sayyids' family was able to answer this issue. Nevertheless, with the great help of Hikayat Misa Melayu and the other later sources, the subsequent holders of Orang Kaya Menteri Paduka Tuan can be traced out accordingly.

After Sayyid Hussein bin Sayyid Jalaluddin, the fourth Orang Kaya Menteri Paduka Tuan was his own brother; Sayyid Abu Bakar. This successive succession between the two brothers had a quite interesting story behind it. According to Hikayat Misa Melayu, when Sayyid Hussein was already being appointed as Orang Kaya Menteri Paduka Tuan by Sultan 
Muzaffar Shah III, Sayyid Abu Bakar also, later on, being appointed as Orang Kaya Bendahara Seri Maharaja. ${ }^{47}$ This meant that during the reign of Sultan Muzaffar Shah III, two offices of the Orang Besar Empat were held by the descendants of Sayyid Hussein alFaradz Jamalullail.

However, Sayyid Abu Bakar did not hold this office for long. Upon the failure of the Orang Besar Empat to fulfil the command of Sultan Iskandar Zulkarnain (1756-1770) to build a new palace, three of them; the Bendahara (Sayyid Abu Bakar), Temenggung, and Orang Kaya Menteri were resigned from their office. ${ }^{48}$ Afterwards, Sayyid Abu Bakar still was being kept near to the palace by Sultan Iskandar Zulkarnain when being appointed as the new Orang Kaya Menteri Paduka Tuan.

It is important to point out that the two great sayyids above; Sayyid Hussein and Sayyid Abu Bakar were sons of Sayyid Jalaluddin bin Sayid Abdul Majid, which also known as Tok Tambak Pulau Pisang. He was reputed as a great 'alim whom flourish during the time of Sultan Iskandar Zulkarnain (1756-1770). ${ }^{49}$ Hence, it was not surprising that his two sons were being appointed to such a high position in the administration of the Perak Sultanate.

The next sayyid that holds the title of Orang Kaya Menteri Paduka Tuan was Sayyid Hashim bin Sayyid Hussein, the grandson of Sayyid Jalaluddin. Then, Sultan Iskandar Zulkarnain (1756-1779) appointed Sayyid Shamsuddin bin Sayyid Abu Bakar to succeed the office. This Sayyid Shamsuddin died in $1780 .{ }^{50} \mathrm{He}$ was replaced later on by Sayyid Usman bin Sayyid Ahmadin bin Sayyid Abu Bakar, a great-grandson of Sayyid Jalaluddin. Sayyid Usman held this position until he died in 1862. Then in 1863, this position was conferred to Cik Ngah Ibrahim by Sultan Ja'afar Muazzam Shah (1857-1865). ${ }^{51}$ Hence, Sayyid Usman was considered as the last holder of Orang Kaya Menteri Paduka Tuan from the sayyids' family.

Despite that, it did not mean their influence in the court of Perak Sultanate was diminished. The descendants of Sayyid Hussein al-Faradz Jamalullail, later on, was trusted with another office of Orang Besar Empat, the office of Orang Kaya Besar Maharaja Diraja. The first holder of this office was Sayyid Mahmud bin Sayyid Shamsuddin. He was appointed by Sultan Ismail (1871-1874). ${ }^{52}$ Later, the great-grandson of previous Sayyid Usman, Sayid Ja'afar bin Sayyid Yunus ${ }^{53}$ bin Sayyid Makah bin Sayyid Usman was appointed to the same office by Sultan Idris Murshidul Azam Shah (1887-1916). ${ }^{54}$ This Sayyid Ja'afar also was the last holder of the manuscript of the Ninety-nine Laws of Perak.

After Sayyid Ja'afar bin Sayyid Yunus, the last recorded sayyids appointed to Orang Kaya Besar Maharaja Diraja was his grandson; Sayyid Abdul Hamid bin Sayyid Saifuddin bin Orang Kaya Besar Sayyid Ja'afar. Nevertheless, the descendants of Sayyid Hussein alFaradz Jamalullail were entrusted with several important offices in the Sultanate of Perak until today. For example, Syed Jaafar bin Syed Aznan Jamalullail which referred in this article is currently holding an office of Toh Muda Orang Kaya Besar Maharaja Diraja. The Toh Muda is the future candidates for Orang Besar Empat. Even his father, Sayyid Aznan bin Sayyid Abdul Hamid Jamalullail was appointed as penghulu for several places in Perak. ${ }^{55}$ 
Figure 1: Genealogy of Sayyid Hussain al-Faradz and his descendants.

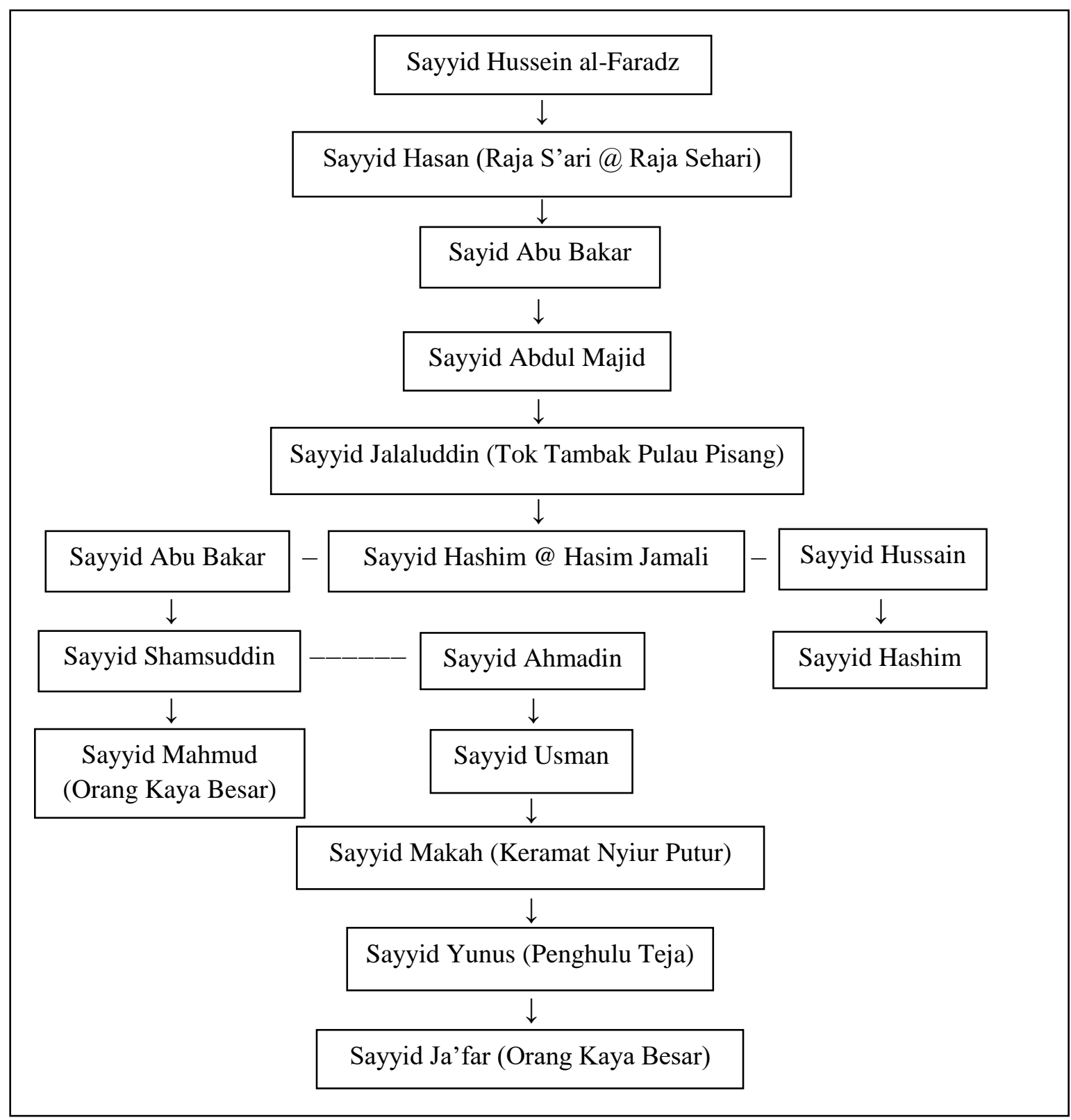

Source: Reproduced from Genealogy of Perak Sultans, MS 40334, SOAS Digital Collections, Folio 4, Windstedt, R.O. "The Hadramaut Sayids of Perak and Siak", Journal of the Straits Branch of the Royal Asiatic Society, Vol. 79, 1919, p. 53, and Syed Jaafar bin Syed Aznan Jamalullail, "Descendants of Syed Husain al-Faradz Jamalullail," Jamalullail Negeri Perak, 2015. Retrieved February 17, 2016. https://sjaznan1.files.wordpress.com/2015/11/silsilahringkas-syed-husain-al-faradz-jamalullail.pdf 


\section{The Connection between the Sayyids and the Perak Royal Family}

Marriage between the Arabs and the Malay royal family was not unknown. Since the era of Malacca Sultanate, this type of marriage took place. ${ }^{56}$ As for the case of the Perak Sultanate, many of the sayyids became husbands of Perak princesses, besides became the spiritual advisors to the rulers. ${ }^{57}$

The first recorded marriage was between Raja Shah Alam, the sister of Sultan Iskandar Zulkarnain with Sayyid Hassan, son of Sayyid Jalaluddin Tok Tambak Pulau Pisang. This marriage begot Raja (Sharif) Bisnu who later married the daughter of Sultan Iskandar Zulkarnain named Raja Sabda Rasul. ${ }^{58}$ This Sharif Bisnu, later on, was appointed by Sultan Iskandar Zulkarnain as Sultan Muda with the title Sultan Muda Alauddin. ${ }^{59}$ A granddaughter from this royal couple, Raja Ngah Aminah was married to Raja Abdullah ${ }^{60}$ who later became Sultan Abdullah Muhammad Shah I (1851-1857). Their son, Raja Yusuf was the Regent of Perak (1877-1886) and Sultan of Perak (1886-1887) with the title of Sultan Yusuf Sharifuddin Muzaffar Shah. ${ }^{61}$ The descendants from this royal marriage later on settled in Chenderiang, Perak. ${ }^{62}$ Raja Haji Yahya, a prominent literary figure mentioned by R.J. Wilkinson and R.O. Winstedt as one of their sources of information regarding Malay history, culture, and literature in Perak, was from this royal marriage lineage. ${ }^{63}$ Raja Haji Yahya also had written in 1908 Salasilah Raja Perak Berhubungan dengan Sayid-Sayid Chandaryang ${ }^{64}$ which relate the genealogy of the Perak royal family and the sayyids of Jamalullail. However, not much information regarding the sayyids family can be extracted from this document apart from the opening and closing phrase in the document which stated respectively:

Sebermula, diceritakan orang yang empunya sahibul riwayat kepada zaman dahulukala, iaitu salasilah asal keturunan raja-raja waris Negeri Perak ini dnegan sayid-sayid yang ada di Chandaryang itu, laksana seperti ibarat nyiur gading, asalnya satu tandan jua, tetapi seumpama emas masing-masing mutunya kepada zaman sekarang.

Demikian inilah keturuanan seperti daftar di dalam list daftar yang hamba tuan permaklumkan empat keeping kertas yang besar ke bawah kaus yang mulia dahulu, salasilah keturunan Sultan Perak ini yang akan jadi perhubungan dengan sayid-sayid (sida-sida) yang sebelah Chandaryang itu. 
Figure 2: Relations Between the sayyids of Perak with the Perak Royal Family.

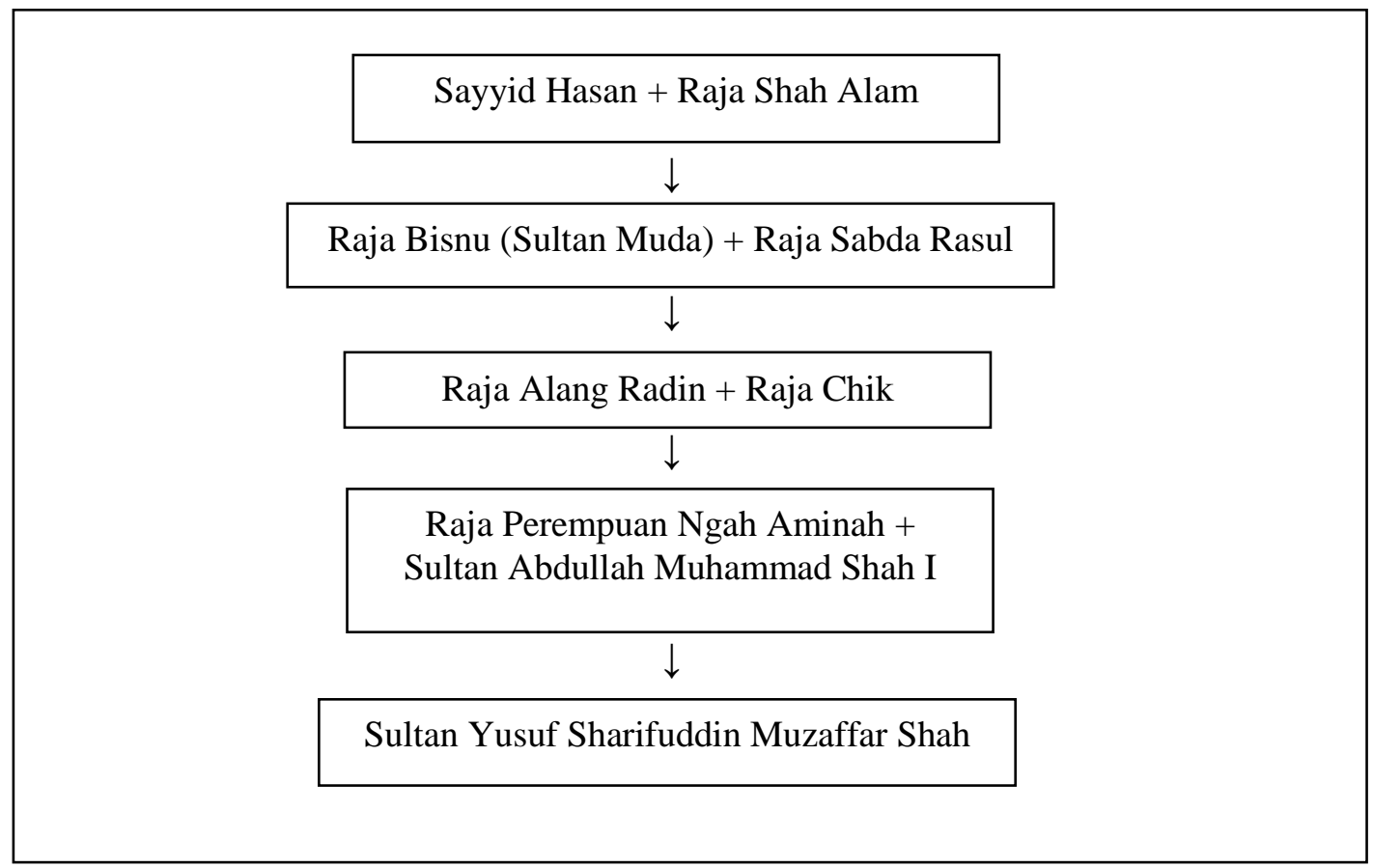

Source: Reproduced from Winstedt, R.O and R.J. Wilkinson, “A History of Perak", Journal of the Malayan Branch of the Royal Asiatic Society, Vol. 12, No. 1, 1934, p. 144.

\section{The Ninety-nine Laws of Perak: The Legacy of the Sayyids of Perak}

The arrival of Islam in the Malay-Indonesian Archipelago brought significant changes in its society especially on the composition of Islamic-based set of laws. The Malay rulers took efforts in incoperating the Islamic laws into the laws of their kingdoms. ${ }^{65}$ Although throughout this process Islamic law was mixed with the local customs, it still indicates a presence of force for Islam behind the attempt to modify Malay customs in accordance with Islamic laws. ${ }^{66}$

Scholars further claimed that since the coming of Islam into the Malay-Indonesian Archipelago, Islamic law has been considered as the law of the land. ${ }^{67}$ Even R.J. Wilkinson, admitted the strong influence of Islam in the Malay traditional law:

Moslem law was in a different position. It rested on something stronger than mere observance and was recorded in imperishable literature. It was gaining ground everywhere when the British authorities come into Malaya ... ${ }^{68}$

Abdul Rahman Abdullah later concluded that, despite all the weaknesses and shortcomings still existing in the Malay traditional laws after the arrival of Islam, the strong and significant influences of Islam in those traditional laws were undeniable as these influences were able to overcome the Hindu and Buddhist influences. ${ }^{69}$ The Ninety-nine Laws of Perak is one of the products of the above-mentioned process. This set of laws belongs to the Sultanate of Perak and was written by the sayyids of Jamalullail. This set of laws was being reputed by R.O. Winstedt as: 
The fullest and most interesting of these laws . . . the trails of non-Muslim native custom is over most sections . . but they afford an interesting side-light on the adoption of Islam by the Malays. ${ }^{70}$

The Ninety-nine Laws of Perak was believed to be brought to Perak by Sayyid Hussein al-Faradz Jamalullail himself, before being revised to accommodate the local customs by his descendants, started with his own son, Sayyid Hassan. The effort continued later by Sayyid Abdul Majid bin Sayyid Abu Bakar bin Sayyid Hassan bin Sayyid Hussein al-Faradz before being completed by Sayyid Jalaluddin Tok Tambak Pulau Pisang. That's why in the preface of this Ninety-Nine Laws of Perak, it was stated that:

Maka turun ke bawah angin ini dibawa Sayid Hassan. Tatkala masa itu Sultan Ahmad Tajuddin Marhum Tanah Abang, nama menterinya Tuan Sayid Abdul Majid, undang-undang jatuh kepada Tuk Tambak, masa bangsa sayid jadi menteri, itulah undang-undang dipakai, satu hukum syarak, dua hukum undang-undang. ${ }^{71}$

Ahmad Jelani Halimi stated that this set of laws contained 40 articles initially before being revised and added to become 99 articles. This can be seen from the preservation of certain elements that are unfamiliar to the Malay-Indonesian environment such as the mentioning of camel, lion, and dirhām. ${ }^{72}$ Meor Ahmad Tajuddin further suggested that the latest revision of this set of laws was done by the grandson of Sayyid Jalaluddin, Sayyid Hashim. ${ }^{73}$ Since then, the following sayyids who became the Orang Kaya Menteri Paduka Tuan used this set of laws as their references. Hence, it can be concluded that this set of laws was revised from time to time, and from one generation to another generation to meet the needs of the Perak society.

Another interesting aspect of this set of laws is that it was in the form of responsa, which is in the form of question and answer, as mentioned earlier. This set of laws is the only one in the Malay-Indonesian Archipelago which is known to have as existed in this form. ${ }^{74}$ Although in the later period exist Mir'at al-Tullāb fì Tashili Ma 'rifat al-Ahkami al-Shar 'iyyah il al-Malik al-Wahhab written between $1661-1672$ by Sheikh Abdul Rauf al-Singkel ${ }^{75}$ and Furū' al-Masā'il wa Ușūl al-Wasā'il by Sheikh Daud bin Abdullah al-Fathani who started to write it from 1838 and completed in $1841^{76}$ and which are also written in the form of responsa, these books focus on fiqh issues or purely on Shari'ah laws. Meanwhile, according to Abu Bakar Abdullah, this responsa form also can be detected in al-Ihkām fì Tamyizi alFatāwā 'Ani al-Ahkām wa Taṣarrufāt al-Qāḍi wa al-Imām, written by Imām al-Qarāfì during the Abbasid period. ${ }^{77}$

The responsa in this set of laws took place between Nushirwan, the Just, and his chief minister, Khoja Bardza Amir Hakim, which signify the Persian influence in this set of laws. Arguments put forward by R.J. Wilkinson further explain this issue:

Another point next suggests itself. We can understand the Malay element and the purely Moslem element, but why is the Persian element so strongly marked in this code? Why does the author try to impress his hearers by referring to Nushirwan and Buzurjmihr instead of quoting Abu Hanifa and Shafei? Here again, we have to go into the family history of these Saiyids. They claim descent from Muhammad through his grandson, Husain, and his greatgrandson, Zainu'l-abedin; ... . it was probably brought into the Saiyids family 
history by the old tradition that a daughter of the last Sasanian king married Hussein, the Prophet's grandson, and became the mother of Zainu'l-abedin, from whom these Perak Saiyids claim descent. ${ }^{78}$

Hence, it can be deduced here that the main reason for the existence of the Persian elements in this set of laws especially the mentioning of Nushirwan, the Just, and his chief minister Khoja Bardza Amir Hakim as the ones who dictated this set of laws is due to the writer's aim to legitimize the authority of this set of laws. This was because the sayyids claimed to be the descendants of Nushirwan, the Just through the marriage of Prophet Muhammad S.A.W.'s grandson, Husayn with one of the princesses of the Sasanian king.

As for the influence of Ninety-nine Laws on the administration of justice in Perak, one local document - Susunan yang Pertama Adat Lembaga Orang-orang Melayu di dalam Negeri Perak Darul Ridzuan daripada Zaman Purbakala - stated that:

(Yang keempat) Orang Kaya Menteri Paduka Tuan hakim besar di atas perkara syarak dan adat (masa Kerajaan yang Kedua) ialah yang menjalankan Undangundang Sembilan Puluh Sembilan istiadat kerajaan Negeri Perak kapitnya Orang Kaya-kaya Imam Paduka Tuan bagi menolong di atas perkara syarak. ${ }^{79}$

Although Susunan yang Pertama Adat Lembaga Orang-orang Melayu di dalam Negeri Perak Darul Ridzuan daripada Zaman Purbakala was only committed to writing in 1935 by a committee composed of royal family members and state's dignitaries, it is believed that the rules and regulations in it had been practised and adhered to for generations in the Perak's court. ${ }^{80}$ Hence, it can be suggested that this set of laws in one way or another influence the administration of justice in Perak. Even though the introduction part of this set of laws stated that ". . . whenever a Sayyid was minister these laws were adopted ..." which led to R.J. Wilkinson and R.O. Winstedt to conclude that it was a mere book of references used by the sayyids' family. ${ }^{81}$ However, as discussed in the earlier part, for generations starting from the early of the $18^{\text {th }}$ century until the middle of the $19^{\text {th }}$ century - the sayyids' family had monopolized the Orang Kaya Menteri Paduka Tuan's office. Since they were also the ones who oversaw religious matters, this set of laws served as a significant reference for them in administering justice for the Perak Sultanate. A remark by Jelani Harun further supported this issue:

Naskhah Undang-undang Sembilan Puluh Sembilan adalah salah sebuah warisan persuratan Negeri Perak yang istimewa dan tinggi nilainya dalam perjalanan sejarah peradaban Negeri Perak, menjadi lambing kewujudan system perundangan awal bagi kesultanan di Negeri Perak, malah juga sebahagian daripada korpus amalan perundangan masyarakat Melayu secara keseluruhannya. $^{82}$ 
Table 1: M.A. Fawzi Mohd Basri's Classification of Articles in the Ninety-nine Laws of Perak.

\begin{tabular}{|c|c|c|c|}
\hline No. & Category & Article(s) & Total \\
\hline 1 & Marriage, Divorce, and Adultery & $\begin{array}{l}6,7,9,30,37,38,39,41, \\
50,54,55,57,65,75,81 \\
82,83,84,85,86,92,93\end{array}$ & 22 \\
\hline 2 & $\begin{array}{l}\text { Protocols Related to the Kings and State's } \\
\text { Dignitaries }\end{array}$ & $\begin{array}{l}1,11,22,24,77,78,96 \\
97,99\end{array}$ & 9 \\
\hline 3 & War & 74 & 1 \\
\hline 4 & Matters Related to the Penghulus & 12,98 & 2 \\
\hline 5 & Matters Related to the Village \& Orchard & $12,21,29,40,43$ & 5 \\
\hline 6 & Slavery and the Infidel & $4,10,16,36$ & 4 \\
\hline 7 & Knowledge and Language & $8,63,64,72$ & 4 \\
\hline 8 & $\begin{array}{l}\text { Rules Related to the Lodger and Lodging } \\
\text { \& House/Transportation Rental }\end{array}$ & $\begin{array}{l}19,26,49,51,76,87,88 \\
89,90\end{array}$ & 9 \\
\hline 9 & Homicide/ Injuries/ Lost of Properties & $2,3,20,23,52,56,71,91$ & 8 \\
\hline 10 & Matters Related to Religion & 58 & 1 \\
\hline 11 & Inheritance, Rich People, and Debts & $17,18,31,33,34,53,55$ & 7 \\
\hline 12 & Medicine/ Pawang/ Midwife & $27,59,60,80,94,95$ & 6 \\
\hline 13 & Judge/ Qā & $25,32,75,79$ & 4 \\
\hline 14 & $\begin{array}{l}\text { Rearing Poultry/ Ghost, Agriculture, and } \\
\text { Trade }\end{array}$ & $\begin{array}{l}14,15,28,42,44,45,46 \\
47,48,69,70\end{array}$ & 11 \\
\hline 15 & Child Without Father and the Bachelors & $5,61,62,67,68,35$ & 6 \\
\hline \multicolumn{3}{|c|}{ Total } & 99 \\
\hline
\end{tabular}

Source: M.A. Fawzi Mohd Basri, Cempaka Sari: Sejarah Kesultanan Negeri Perak, Perak: Yayasan Perak, 1986, p. 233. 


\section{Conclusion}

From the above discussion, it is clear that the Jamalullail of Perak had arrived in Perak as early as the $16^{\text {th }}$ century, not the $17^{\text {th }}$ century as claimed by several scholars. It is also proven that they had played significant roles in the Perak Sultanate as stated by R.J. Wilkinson and Mohamed Redzuan Othman earlier. Throughout the early $18^{\text {th }}$ until the middle of $19^{\text {th }}$ century, they had monopolized the position of Orang Kaya Menteri Paduka Tuan which look over the matter of shara' in the Perak Sultanate and contributed significantly to the Islamisation the Perak society, especially with the compilation of Islamic-based laws; Undang-undang Sembilan Puluh Sembilan. Several saints in Perak also descended from their lineages such as above mentioned Sayyid Jalaluddin (Tok Tambak Pulau Pisang) and Sayyid Mekah (Keramat Nyior Putur). ${ }^{83}$

Although in the middle of the $19^{\text {th }}$ century they were no longer hold the position as Orang Kaya Menteri Paduka Tuan, they were still trusted with others important positions such as Orang Kaya Besar Maharaja Diraja (also one of the Orang Besar Empat of the Perak Sultanate) and being appointed as Penghulu in several districts in Perak. Their position further enhanced by the intermarriage with the Perak's royal family, which lead to the emergence of Raja Haji Yahya, a trusted custodian of the Malay history, culture, and literature in Perak. Hence, their significant contributions and close connection with the Perak Sultanate had made them being revered and respected in the Perak society which made their genealogy deem worthy to be included in the Genealogy of Perak Sultans as mentioned earlier.

After all, it is the task of contemporary scholars to study and present their history to the world. Fortunately, although being marginal in the academic world, the Jamalullail of Perak always concerned about the preservation of their oral tradition. Numerous works had been done by them to preserve their history, heritage, and genealogy. What is left for contemporary scholars is to approach them and record their history academically for future generation's knowledge. Hopefully, this preliminary study will ignite interest among scholars for further comprehensive researches in the future.

Note

* Mr. Mohamad Hazizie bin Sulkafle (haziziesulkafle@gmail.com) is currently a PhD candidate at International Institute of Islamic Thought and Civilisation, International Islamic University Malaysia (IIUM), with his area of study on the statecraft of the Sultanate of Perak in the 18th and 19th century

${ }^{1}$ William R. Roff, The Origins of Malay Nationalism, Singapore: University of Malaya Press, 1967, p. 41.

2 J.A.E. Morley, “The Arabs and the Eastern Trade", Journal of Malayan Branch of Royal Asiatic Society, Vol. 22, Part 1, 1949, p. 145, and Abdul Rahman Abdullah, Sejarah dan Tamadun Asia Tenggara: Sebelum dan Sesudah Pengaruh Islam, Kuala Lumpur: Utusan Publications \& Distributors Sdn Bhd, 2009, p. 216.

3 Abdul Rahman Abdullah, Sejarah dan Tamadun Asia Tenggara, p. 217, and Ahmad Syalabi, Ensiklopedia Sejarah Islam, translated from Arabic by H.M. Yusuf Sinaga and Hj. Abdurrahman Saleh Siregar, Selangor: Jasmin Publications, 2010, p. 30.

${ }^{4}$ Abdul Rahman Abdullah, Sejarah dan Tamadun Asia Tenggara, p. 217. 
${ }^{5}$ Haji Dusuki Haji Ahmad, Ikhtisar Perkembangan Islam, Kuala Lumpur: Dewan Bahasa dan Pustaka, 1993, p. 511.

${ }^{6}$ Thomas W. Arnold, The Spread of Islam in the World, New Delhi: Goodword Books, 2012, p. 364.

${ }^{7}$ Ibid.

${ }^{8}$ Paul Wheatley, The Golden Khersonese, Kuala Lumpur: University of Malaya Press, 2010, pp. $210-211$.

9 Abdul Rahman Tang Abdullah, "Arab Hadhramis in Malaysia: Their Origins and Assimilation in Malay Society" in Ahmed Ibrahim Abushouk and Hassan Ahmed Ibrahim (ed.s), The Hadhrami Diaspora in Southeast Asia: Identity Maintenance or Assimilation?, Leiden: Brill, 2009, p. 47.

${ }^{10}$ Mahayudin Haji Yahaya, "Latar belakang Keturunan Sayid di Malaysia” in Mahayudin Haji Yahaya (ed.), Islam di Alam Melayu, Kuala Lumpur: Dewan Bahasa dan Pustaka, 2001, p. 160.

11 Ulrike Freitag, "Reflections on the Longevity of the Hadhrami Diaspora in the Indian Ocean" in Ahmed Ibrahim Abushouk and Hassan Ahmed Ibrahim (eds.), The Hadhrami Diaspora in Southeast Asia: Identity Maintenance or Assimilation?, Leiden: Brill, 2009, pp. 22-23.

${ }^{12}$ Syed Muhammad Naquib al-Attas, Historical Fact and Fiction, Kuala Lumpur: UTM Press, 2011, pp. 99-100 and 104.

${ }^{13}$ R. Michael Feener and Michael F. Laffan, "Sufi Scents Across the Indian Ocean: Yemeni Hagiography and the Earliest History of Southeast Asian Islam”, Archipel, Vol. 70, 2005, p. 186.

${ }^{14}$ Syed Muhammad Naquib al-Attas, Islam dalam Sejarah dan Kebudayaan Melayu, Kuala Lumpur: Angkatan Belia Islam Malaysia, 1999, p. 43, and Michael Francis Laffan, Islamic Nationhood and Colonial Indonesia: The Umma Below the Winds, London: RoutledgeCurzon, 2003, p. 13. See also Wan Kamal Nadzif Wan Jamil and Saidi Adnan Md Noor, "Bangsa Melayu dan Jawi dalam Kitab Turath Arab", Jawhar: Jurnal of Civilisational Studies, Vol. 11, 2014, pp. 20-50 for an interesting discussion on this issue.

${ }^{15}$ Feener and Laffan, "Sufi Scents Across the Indian Ocean, p. 188.

16 R.B. Sergeant, "The Saiyids of Hadramawt" in R.B. Sergent (ed.), Studies in Arabian History and Civilisation, London: Variorum Reprints, 1981, pp. 3-29, and Mahayudin Haji Yahaya, Islam di Alam Melayu, 141-164.

${ }^{17}$ However, it is reminded that further discussion to prove their claims as Ahl al-Bayt is beyond the scope of this paper.

${ }^{18}$ Mahayudin Haji Yahaya, Sejarah Orang Syed di Pahang, Kuala Lumpur: Dewan Bahasa dan Pustaka, 1984.

${ }^{19}$ Mohamad Redzuan Othman, "Hadhramis in the Politics and Administration of the Malay States in the Late Eighteenth and Nineteenth Centuries" in Ulrike Freitag and William Clarence-Smith (eds.), Hadhrami Traders, Scholars, and Statemen in the Indian Ocean, 1750s - 1960s, Leiden: Koninklijke Brill, 1997, pp. 82-93 and Abdul Rahman Tang, "Arab Hadhramis in Malaysia”, pp. 45-56. See also Jeyamalar Kathirithamby-Wells, "'Strangers' and 'Stranger-Kings': The Sayyid in Eighteenth-Century Maritime Southeast Asia", Journal of Southeast Asian Studies, Vol. 40, No. 3, 2009, pp. 567-91.

${ }^{20}$ W.E. Maxwell, "Notes and Queries", Journal of Straits Branch of the Royal Asiatic Society, No. 3, 1886 , p. 70 .

${ }^{21}$ M.A. Fawzi Mohd Basri, Cempaka Sari: Sejarah Kesultanan Negeri Perak, Ipoh: Yayasan Perak, 1986, p. 266.

${ }^{22}$ R.O. Windstedt, “The Hadramaut Sayids of Perak and Siak", Journal of the Straits Branch of the Royal Asiatic Society, Vol. 79, 1919, p. 51.

${ }^{23}$ Liaw Yock Fang, Sejarah Kesusasteraan Melayu Klasik, Jakarta: Yayasan Pustaka Obor Indonesia, 2011, p. 470.

${ }^{24}$ Raja Chulan, Misa Melayu, ed. R.O. Winstedt, Kuala Lumpur: Pustaka Antara, 1991, p. 205.

${ }^{25}$ Ibid.

${ }^{26}$ M.A. Fawzi Mohd Basri, Cempaka Sari, p. 266.

${ }^{27}$ Ibid.

${ }^{28}$ Liaw Yock Fang, Kesusasteraan Melayu Klasik, p. 470. 
${ }^{29}$ R.O. Winstedt, A History of Classical Malay Literature, Kuala Lumpur: Malaysia Branch of Royal Asiatic Society, $3^{\text {rd }}$ edn., 1991, p. 114.

${ }^{30}$ Ibid, p. 113.

${ }^{31}$ Barbara Watson Andaya, Perak, the Abode of Grace: A Study of an Eighteenth-Century Malay State, Kuala Lumpur: Oxford University Press, 1979, pp. 159-160.

${ }^{32}$ R.O. Winstedt and R.J. Wilkinson, "A History of Perak", Journal of Malayan Branch of the Royal Asiatic Society, Vol. 12, Part 1, June 1934, p. 126.

${ }^{33}$ M.A. Fawzi Mohd Basri, Cempaka Sari, p. 21.

${ }^{34}$ Ibid.

${ }^{35}$ It must be noted also that since in the middle of the $16^{\text {th }}$ century until this period $\left(17^{\text {th }}\right.$ century), Perak was under the influence of the Acheh Sultanate. Even the previous Sultan Salehudin was taken as a captive to Acheh after Perak being attacked by Acheh and he died there.

36 Andaya, Perak, p. 61.

${ }^{37}$ Ibid., 161.

${ }^{38}$ Raja Chulan Ibn Raja Hamid, Hikayat Misa Melayu, ed. Jelani Harun, Kuala Lumpur: RNS Publication and Yayasan Karyawan, 2015, pp. 6 and 194-195 (endnote no. 9).

${ }^{39}$ Ibid.

${ }^{40}$ R.J. Wilkinson, "Preface", in R.J. Wilkinson (ed.), Papers on Malay Subject: Law Part II: The Ninety-nine Laws of Perak, Kuala Lumpur: Federated Malay States Government Press, 1929, p. 7.

${ }^{41}$ Mohamad Redzuan Othman, "Hadhramis in the Politics and Administration of the Malay States", p. 87.

${ }^{42}$ N.A. Halim, Tempat-tempat Bersejarah Perak, Kuala Lumpur: Jabatan Muzium Negara, 1981, p. 82.

${ }^{43}$ The titles of Orang Besar Empat Perak are as follow: 1) Orang Kaya Bendahara Seri Maharaja, 2) Orang Kaya Besar Maharaja Diraja, 3) Orang Kaya Temenggung Paduka Raja, and 4) Orang Kaya Menteri Paduka Tuan. See R.O. Winstedt and R.J. Wilkinson, “A History of Perak”, pp. 137-145 for brief discussion on their responsibilities and historical development.

${ }^{4}$ Susunan yang Pertama Adat Lembaga Orang-orang Melayu di dalam Negeri Perak Darul Ridzuan daripada Zaman Purbakala, Taiping: Matba'ah al-Ziniyyah, 1935, p. 11.

${ }^{45}$ M.A. Fawzi Mohd Basri, Cempaka Sari, p. 251.

${ }^{46}$ Raja Chulan Ibn Raja Hamid, Hikayat Misa Melayu, p. 8.

${ }^{47}$ Ibid., 30.

48 Ibid., 89.

${ }^{49}$ N.A. Halim, Tempat-tempat Bersejarah Perak, p. 94.

${ }^{50}$ Ibid., p. 100.

${ }^{51}$ Ibid., pp. 108-109.

${ }^{52}$ M.A. Fawzi Mohd Basri, Cempaka Sari, p. 144.

${ }^{53}$ His father, Sayyid Yunus also was being trusted as Penghulu of Teja district.

${ }^{54}$ N.A. Halim, Tempat-tempat Bersejarah Perak, p. 144.

55 Syed Jaafar bin Syed Aznan Jamalullail. “Syed Aznan Jamalullail”, Jamalullail Negeri Perak, 2015. Retrieved February 17, 2016. https://sjaznan1.wordpress.com/2015/06/11/syed-aznan-jamalullail/

${ }^{56}$ Mohamad Redzuan Othman, "Hadhramis in the Politics and Administration of the Malay States", p. 84.

57 Andaya, Perak, p. 165.

58 W.E. Maxwell, “The History of Perak from Natives Sources', Journal of the Straits Branch of the Royal Asiatic Society, Vol. 14, 1885, pp. 307-308.

${ }^{59}$ Winstedt \& Wilkinson, “A History of Perak”, p. 135.

${ }^{60}$ Maxwell, "The History of Perak”, p. 312.

${ }^{61}$ Ibid., p. 316 and M.A. Fawzi Basri, Cempaka Sari, p. 267.

${ }^{62}$ Jelani Harun, Umpama Sebuah Bahtera, p.22. 
${ }^{63}$ For further discussion regarding Raja Haji Yahya, please refer to ibid, pp. 17-28 and Jelani Harun, Ibarat Nyiur Gading: Raja Haji Yahya dalam Sejarah Kesusasteraan Melayu Abad ke-20, Pulau Pinang: Penerbit Universiti Sains Malaysia, 2018.

${ }^{64}$ Salasilah Raja Perak Berhubungan dengan Sayid-Sayid Chandaryang, ANM SP 9/2003/0008167, National Archive of Malaysia. For further discussion regarding this document, please refer to Jelani Harun, Umpama Sebuah Bahtera, pp. 17-43 and Jelani Harun, “Asal-usul Raja, Negeri dan Adat Istiadat Kesultanan Perak: Beberapa Variasi dalam Pengekalan dan Penyimpangan Sumber Tradisi," Sari: International Journal the Malay World and Civilisation, Vol. 29, No. 1, 2011, pp. 3-35.

65 Jelani Harun, Umpama Sebuah Bahtera, p. 91, Abdullah Alwi Hassan, "Pertumbuhan Pentadbiran Undangundang Islam di Malaysia" in Mohd. Taib Osman and A. Aziz Deraman (eds.), Tamadun Islam di Malaysia, Kuala Lumpur: Dewan Bahasa dan Pustaka, 2000, p. 126, and Ahmed Ibrahim and Ahilemah Joned, Sistem Undang-undang di Malaysia, Kuala Lumpur: Dewan Bahasa dan Pustaka, 2nd edn., 2013, p. 48.

${ }^{66}$ Muhammad Haniff Hassan, "Explaining Islam's Special Position and the Politics of Islam in Malaysia", The Muslim World, Vol. 97, April 2007, p. 288.

${ }^{67}$ Abdul Majeed Mohamed Mackeen, Contemporary Islamic Legal Organization in Malaya, Monograph Series No. 13, New Haven: Yale University Southeast Asia Studies, 19669, p. 9.

${ }^{68}$ R.J. Wilkinson, Papers on Malay Subjects: Law Part I, Introductory Sketch, Kuala Lumpur: Federated Malay States Government Press, 1922, p. 49.

${ }^{69}$ Abdul Rahman Abdullah, Sejarah dan Tamadun Asia Tenggara, p. 381.

${ }^{70}$ Winstedt, A History of Classical Malay Literature, p. 120.

71 Undang-undang Sembilan Puluh Sembilan Perak, ANM No. SP/48/2007/0052706, National Archive of Malaysia.

${ }^{72}$ Ahmad Jelani Halimi, "Pengaruh Islam Terhadap Perundangan Melayu: Tumpuan kepada Undang-undang 99 Perak", in Farid Mat Zin (ed.), Islam di Tanah Melayu Abad ke-19, Shah Alam: Karisma Publications Sdn. Bhd., 2007, p. 75.

${ }^{73}$ Meor Ahmad Tajuddin Meor Mazlan, Tun Sab'an dan Pembesar Melayu Perak, Ipoh: Yayasan Perak, 2005, pp. 132-133.

${ }^{74}$ M.B. Hooker, Introductory Note to "The Ninety-nine Laws of Perak", in M.B. Hooker (ed.), Readings in Malay Adat Laws, Singapore: Singapore University Press, 1970, pp. 55-56.

75 See Abu Hassan Sham and Mariyam Salim, Sastera Undang-undang, Kuala Lumpur: Dewan Bahasa dan Pustaka, 1995, p. 152, Jelani Harun, Undang-undang Kesultanan Melayu dalam Perbandingan, Pulau Pinang: Penerbit USM, 2010, pp. 88 and 314-315, and Jelani Harun, "Mir'at al-Tullab by Syeikh Abdul Rauf Singkel: A Preliminary Study of Manuscripts Kept in the Special Collections, Leiden University Library", Malay Literature, Vol. 26, No. 2, 2013, pp. 119-138.

${ }^{76}$ See Abdul Kadir Haji Muhammad, Sejarah Penulisan Hukum Islam di Malaysia, Kuala Lumpur: Dewan Bahasa dan Pustaka, 1996, pp. 43-44 and Hadewan Towpek, "Writing Methods of Syeikh Daud al-Fatani in Furū‘ al-Masā'il with Special Focus on Muamalat Chapter”, Journal of Fiqh, No. 10, 2013, pp. 1-30.

77 Abu Bakar Abdullah, (ed.), Ke Arah Perlaksanaan Undang-undang Islam di Malaysia, Kuala Terengganu: Pustaka Damai, 1986, p. 65.

78 R.J. Wilkinson, "Preface", pp. 5-6.

${ }^{79}$ Susunan yang Pertama Adat Lembaga Orang-orang Melayu di dalam Negeri Perak Darul Ridzuan daripada Zaman Purbakala, p. 11.

${ }^{80}$ Jelani Harun, Umpama Sebuah Bahtera, pp. 125-133.

${ }^{81}$ Wilkinson, "Preface", p. 1, and Winstedt, A History of Classical Malay Literature, p. 120.

82 Jelani Harun, Umpama Sebuah Bahtera, p. 101.

83 Syed Jaafar bin Syed Aznan Jamalullail, "Genealogi Jamalullail Negeri Perak," Jamalullail Negeri Perak, 2015. Retrieved February 17, 2016. https://sjaznan1.wordpress.com/2015/11/08/genealogy-jamalullail-negeriperak 


\section{Reference}

\section{Primary sources}

Genealogy of Perak Sultans, MS 40334, SOAS Digital Collections.

Raja Chulan Ibn Raja Hamid, Hikayat Misa Melayu, edited by Jelani Harun, Kuala Lumpur: Yayasan Karyawan, 2015.

Raja Chulan, Misa Melayu, edited by R.O. Winstedt, Kuala Lumpur: Pustaka Antara, 1991.

Salasilah Raja Perak Berhubungan dengan Sayid-Sayid Chandaryang, ANM SP 9/2003/2003/0008167, National Archive of Malaysia.

Susunan yang Pertama Adat Lembaga Orang-Orang Melayu di dalam Negeri Perak Darul Ridzuan Daripada Zaman Purbakala, Taiping: Matba'ah al-Ziniyyah, 1935.

Undang-undang Sembilan Puluh Sembilan Perak, ANM No. SP/48/2007/0052706, National Archive of Malaysia.

\section{Secondary Sources}

Abdul Kadir Haji Muhammad, Sejarah Penulisan Hukum Islam di Malaysia. Kuala Lumpur: Dewan Bahasa dan Pustaka, 1996.

Abdullah Alwi Hassan, "Adat Melayu Mengikut Perpsektif Perundangan Islam di Malaysia", in Abdul Latif Abu Bakar (ed.), Adat Melayu Serumpun: Adat Bersendi Syarak, Syarak Bersendi Kitabullah, Melaka: Perbadanan Muzium Melaka, 2001.

Abdul Majeed Mohamed Mackeen, Contemporary Islamic Legal Organization in Malaya, Monograph Series No. 13, New Haven: Yale University Southeast Asia Studies, 1969.

Abdul Rahman Abdullah, Sejarah dan Tamadun Asia Tenggara: Sebelum dan Sesudah Pengaruh Islam. Kuala Lumpur: Utusan Publications \& Distributors Sdn. Bhd, 2009.

Abdul Rahman Tang Abdullah, "Arab Hadhramis in Malaysia: Their Origins and Assimilation in Malay Society", in Ahmed Ibrahim Abushouk and Hassan Ahmed Ibrahim (eds.), The Hadhrami Diaspora in Southeast Asia: Identity Maintenance or Assimilation?, Leiden: Brill, 2009.

Abu Bakar Abdullah, (ed.), Ke Arah Perlaksanaan Undang-undang Islam di Malaysia. Kuala Terengganu: Pustaka Damai, 1986.

Abu Hassan Sham and Mariyam Salim, Sastera Undang-undang. Kuala Lumpur: Dewan Bahasa dan Pustaka, 1995.

Ahmad Ibrahim and Ahilemah Joned, Sistem Undang-undang di Malaysia, Kuala Lumpur: Dewan Bahasa dan Pustaka, 2013. 
Ahmad Jelani Halimi, "Pengaruh Islam Terhadap Perundangan Melayu: Tumpuan kepada Undang-undang 99 Perak", in Farid Mat Zin (ed.), Islam di Tanah Melayu Abad ke19, Shah Alam: Karisma Publications Sdn. Bhd, 2007.

Ahmad Syalabi, Ensiklopedia Sejarah Islam, Selangor: Jasmin Publications, 2010.

Al-Attas, Syed Muhammad Naquib, Historical Fact and Fiction, Kuala Lumpur: UTM Press, 2011.

Al-Attas, Syed Muhammad Naquib, Islam dalam Sejarah dan Kebudayaan Melayu, Kuala Lumpur: Angkatan Belia Islam Malaysia, 1999.

Andaya, Barbara Watson, Perak, The Abode of Grace: A Study of an Eighteenth-Century Malay State, Kuala Lumpur: Oxford University Press, 1979.

Arnold, Thomas W, The Spread of Islam in the World, New Delhi: Goodword Books, 2012.

Feener, R. Michael and Michael F. Laffan, "Sufi Scents Across the Indian Ocean: Yemeni Hagiography and the Earliest History of Southeast Asian Islam", Archipel, Vo.1. 70, 2005.

Hadewan Towpek, "Writing Methods of Syeikh Daud al-Fatani in Furū' al-Masā'il with Special Focus on Muamalat Chapter", Journal of Fiqh, No. 10, 2013.

Haji Dusuki Haji Ahmad, Ikhtisar Perkembangan Islam, Kuala Lumpur: Dewan Bahasa dan Pustaka, 1993.

Hooker, M.B, "Introductory Note to The Ninety-nine Laws of Perak", in M.B. Hooker (ed.), Readings in Malay Adat Laws, Singapore: Singapore University Press, 1970.

Jelani Harun, “Asal-Usul Raja, Negeri, dan Adat Istiadat Kesultanan Perak: Beberapa Variasi dalam Pengekalan dan Penyimpangan Sumber Tradisi", Sari: International Journal of the Malay World and Civilisation, Vol. 29, No.1, 2011.

Jelani Harun, Ibarat Nyiur Gading: Raja Ali Haji dalam Sejarah Kesusasteraan Melayu Abad ke-20, Pulau Pinang: Penerbit Universiti Sains Malaysia, 2018.

Jelani Harun, "Mir'at al-Tullab by Syeikh Abdul Rauf Singkel: A Preliminary Study of Manuscripts Kept in the Special Collections, Leiden University Library", Malay Literature, Vol. 26, No. 2, 2013

Jelani Harun, Undang-undang Kesultanan Melayu dalam Perbandingan, Pulau Pinang: Penerbit USM, 2010.

Jelani Harun, Umpama Sebuah Bantera: Kajian Naskhah Melayu Sejarah Kesultanan Negeri Perak, Kuala Lumpur: Arkib Negara Malaysia, 2011.

Kathirithamby-Wells, Jeyamalar, "'Strangers' and 'Stranger-Kings': The Sayyid in EighteenthCentury Maritime Southeast Asia", Journal of Southeast Asian Studies, Vol. 40, No. 3, 2009. 
Laffan, Michael Francis, Islamic Nationhood and Colonial Indonesia: The Umma Below the Winds, London: RoutledgeCurzon, 2003.

Liaw, Yock Fang, Sejarah Kesusastraan Melayu Klasik, Jakarta: Yayasan Pustaka Obor Indonesia, 2011.

M.A. Fawzi Mohd Basri, Cempaka Sari: Sejarah Kesultanan Negeri Perak, Perak: Yayasan Perak, 1986.

Mahayudin Haji Yahaya, "Latar belakang Keturunan Sayid di Malaysia", in Mahayudin Haji Yahaya (ed.), Islam di Alam Melayu, Kuala Lumpur: Dewan Bahasa dan Pustaka, 2001.

Mahayudin Haji Yahaya, Sejarah Orang Syed di Pahang, Kuala Lumpur: Dewan Bahasa dan Pustaka, 1984.

Maxwell, W.E., "Notes and Queries", Journal of the Straits Branch of the Royal Asiatic Society, No. 3, 1886.

Maxwell, W.E., "The History of Perak from Natives Sources," Journal of the Straits Branch of the Royal Asiatic Society, Vol. 14, 1885.

Meor Ahmad Tajuddin Meor Mazlan, Tun Sab'an dan Pembesar Melayu Perak. Ipoh: Yayasan Perak, 2005.

Mohamad Redzuan Othman, "Hadhramis in the Politics and Administration of the Malay States in the Late Eighteenth and Nineteenth Centuries", in Ulrike Freitag and William Clarence-Smith (eds.), Hadhrami Traders, Scholars, and Statemen in the Indian Ocean, 1750s - 1960s, Leiden: Koninklijke Brill, 1970.

Morley, J.A.E., "The Arabs and the Eastern Trade", Journal of Malayan Branch of Royal Asiatic Society, Vol. 22, No. 1, 1949.

Muhammad Haniff Hassan, "Explaining Islam's Special Position and the Politic of Islam in Malaysia,” The Muslim World, Vol. 97, 2007.

N.A. Halim, Tempat-tempat Bersejarah Perak, Kuala Lumpur: Jabatan Muzium Negara, 1981.

Roff, William R., The Origins of Malay Nationalism, Singapore: University of Malaya Press, 1967.

Sergeant, R.B., "The Saiyids of Hadramawt", in R.B. Sergent (ed.), Studies in Arabian History and Civilisation, London: Variorum Reprints, 1981.

Syed Jaafar bin Syed Aznan Jamalullail, "Descendants of Syed Husain al-Faradz Jamalullail", Jamalullail Negeri Perak, 2015. Retrieved February 17, 2016. https://sjaznan1.files.wordpress.com/2015/11/silsilah-ringkas-syed-husain-al-faradzjamalullail.pdf 
Syed Jaafar bin Syed Aznan Jamalullail, “Genealogi Jamalullail Negeri Perak,” Jamalullail Negeri Perak, 2015. Retrieved February 17, 2016. https://sjaznan1.wordpress.com/2015/11/08/genealogy-jamalullail-negeri-perak/

Syed Jaafar bin Syed Aznan Jamalullail, "Syed Aznan Jamalullail," Jamalullail Negeri Perak, 2015. $\quad$ Retrieved $\quad$ February 17, 2016. https://sjaznan1.wordpress.com/2015/06/11/syed-aznan-jamalullail/

Ulrike Freitag, "Reflections on the Longevity of the Hadhrami Diaspora in the Indian Ocean" in Ahmed Ibrahim Abushouk and Hassan Ahmed Ibrahim (eds.), The Hadhrami Diaspora in Southeast Asia: Identity Maintenance or Assimilation?, Leiden: Brill, 2009.

Wan Kamal Nadzif Wan Jamil and Saidi Adnan Md Noor, "Bangsa Melayu dan Jawi dalam Kitab Turath Arab”, Jawhar: Jurnal of Civilisational Studies, Vol. 11, 2014.

Wheatley, Paul, The Golden Khersonese, Kuala Lumpur: University of Malaya Press, 2010.

Wilkinson, R.J., Papers on Malay Subjects: Law Part I, Introductory Sketch, Kuala Lumpur: Federated Malay States Government Press, 1922.

Wilkinson, R.J., "Preface", in R.J. Wilkinson (ed.), Papers on Malay Subjects: Law Part II: The Ninety-nine Laws of Perak, Kuala Lumpur: Federated Malay States Government Press, 1929.

Winstedt, R.O., A History of Classical Malay Literature, Kuala Lumpur: Malaysia Branch of Royal Asiatic Society, 1991.

Winstedt, R.O., "The Hadramaut Sayids of Perak and Siak”, Journal of the Straits Branch of the Royal Asiatic Society, Vol. 79, 1919.

Winstedt, R.O. and R.J. Wilkinson, "A History of Perak", Journal of the Malayan Branch of the Royal Asiatic Society, Vol. 12, No. 1, 1934. 